\title{
QUALITATIVE RESEARCH IN NEUROLINGUISTICS: THE CASE OF WORD FINDING DIFFICULTIES AND RELATED PHENOMENA
}

\author{
ROSANA DO CARMO NOVAES PINTO ${ }^{1}$ \\ (UNICAMP/CNPQ)
}

\begin{abstract}
RESUMO: Este artigo visa apresentar e discutir fenômenos relacionados às chamadas "Dificuldades de Encontrar Palavras" (WFD), dentre os quais a produção de fala telegráfica, de parafasias, de paralexias, as palavras na ponta da língua (da expressão em inglês: Tip-of-the tongue - TOT) e a emergência desses fenômenos nos processos de envelhecimento normal. Em contraste com a abordagem quantitativa e estatística dessas questões, por meio de instrumentos psicométricos, argumentamos a favor da análise qualitativa de episódios dialógicos, buscando uma melhor compreensão do funcionamento semântico-lexical. Os princípios teóricos, metodológicos e éticos do estudo fundamentam-se, principalmente, nos postulados de Coudry ([1986], 1988), desde a publicação do Diário de Narciso: discurso e afasia.

Palavras-chave: Neurolinguística Discursiva; Afasia; Dificuldades para Encontrar Palavras (WFD); Pesquisa Qualitativa.
\end{abstract}

RÉSUMÉ: Cet article vise à présenter et discuter des phénomènes liés à la soi-disant «Difficulté de Trouver les Mots» (de l'expression anglaise Word Finding Difficulties - $\underline{\text { WFD }}$ ), parmi lesquels la production de la parole télégraphique, des paraphasies, de paralexies, les mots sur la-pointe-dela-langue (de l'expression anglaise Tip of the tongue - TOT) et l'emmergence de ces phénomènes dans le processus de vieillissement normal. Contrairement à l'approche quantitative et statistique de ces questions, au moyen d'instruments psychométriques, nous plaidons en faveur de l'analyse qualitative des épisodes dialogiques, en cherchant une meilleure compréhension du fonctionnement sémantique-lexical. Les principes théoriques, méthdologiques et éthiques de l'étude reposent principalement sur les postulats de Coudry ([1986], 1988), depuis la publication de Diário de Narciso : discours et aphasia.

Mots-clés: Neurolinguistique Discursive, Aphasie, Difficultés à trouver des mots (WFD); Recherche Qualitative.

${ }^{1}$ Associated Professor at the Department of Linguistics, Institute of Language Studies, University of Campinas (UNICAMP). Contact: ronovaes@,iel.unicamp.br 


\section{FOREWORD: IN HONOR OF MARIA IRMA HADLER COUDRY ${ }^{2}$}

The reflections developed in this article ${ }^{3}$ are strongly based on theoreticalmethodological and ethical principles postulated by Maria Irma Hadler Coudry in 1986, in her doctoral thesis named Diário de Narciso: avaliação e acompanhamento longitudinal de linguagem de sujeitos afásicos de uma perspectiva discursiva, published two years later as Diário de Narciso: discurso e afasia ${ }^{4}$.

In order to better understand the relationship between brain and language, Coudry grounded her work on neuropsychological socio-cultural theories and on pragmatic-discursive perspectives ${ }^{5}$, incorporating subjectivity in evaluation and follow-up activities with aphasic individuals; i.e., considered the "social use of language". Thus, aphasics - despite aphasia - are considered "subjects of language ${ }^{6 "}$. Coudry, either in her classes or in the articles and chapters written, has always underlined that "there is language in aphasia" and emphasized the role of the interlocutor, as well as the need of mutual and shared knowledge, in the process of signification.

As it will be pinpointed along the article, the postulates developed by Coudry have not only guided research practices in Neurolinguistics, but also inaugurated a community extension project with and for aphasic individuals at Centro de Convivência de Afásicos (CCA) ${ }^{7}$ - the locus where theoretical and methodological

${ }^{2}$ I feel very privileged to have been one of Coudry's first students and been supervised by her throughout my post-graduation studies (MA and PhD research on aphasia: Novaes-Pinto, 1992; Novaes-Pinto, 1999). As a professor of the Department of Linguistics since 2004, I am still able to witness the enchantment people (including my own studentes) have for her work and for the humanity she added to the activities developed in the field of Neurolinguistics. For all these reasons, I dedicate to Prof. Maza this reflection, on the celebration of the 30-year anniversary of the publishing of Diário de Narciso.

${ }^{3}$ The choice to present this article in English has to do with a personal desire - and a need - to publicize Discursive Neurolinguistics in a wider circuit, as already done in Novaes-Pinto (2012b). As we will see ahead, this perspective is not yet enough spread in academic and clinical practices outside Brazil. Research like the ones carried out by Damico et al. (1999a, 1999b) - who approach aphasia within a qualitative methodology - sounded a novelty at the time of their first publications, but we should recognize that Coudry ([1986] 1988) anticipated in more than a decade the questions the authors address.

${ }^{4}$ The doctoral thesis was named: Narciso's Diary: assessment and language longitudinal followup of aphasic subjects from a discursive perspective, edited as a book by Martins Fontes, in 1988, as Narciso's Diary: discourse and aphasia (1988). Just as a note, Narciso was one of the aphasic subjects with whom Coudry worked during her doctoral research. The term diary relates to the methodology she developed for the language follow-up, in which the subjects usually report their everyday activities.

${ }^{5}$ Such as Discourse Analysis, Pragmatics, Semantics of Enunciation and Language Acquisition developed in the $60 \mathrm{~s}$ and $70 \mathrm{~s}$ of the $20^{\text {th }}$ century.

${ }^{6}$ Although the word "individual" is frequently used in this text to refer to a person with aphasia, the concept of "subject" is more appropriated within a discursive perspective, aiming to highlight the active work developed by aphasics along the processes of signification and language reorganization. "Subject" is used as opposed to the term "patient", very recurrent in aphasiology.

${ }^{7}$ Located at IEL, CCA is a locus for the interaction among aphasic and non-aphasic subjects: researchers, professors, families, therapists, undergraduate and post-graduate students (Coudry, 2002). CCA is, according to the author, an institutional alternative that aims to integrate aphasics in their social groups. 
principles meet. These guidelines that started to be developed in the late 80s have inspired hundreds of works in the field of Neurolinguistics in all levels of research.

While dominant approaches in Neurolinguistics privilege abstract models of language functioning, the social-cultural theories - mainly the ones proposed by Luria (1973, 1976, 1977, 1986) and Vygotsky ([1930] 1984; [1934] 1987), among other authors - envisage language as a very complex activity ${ }^{8}$ developed by subjects within social and cultural contexts. The authors also highlighted the relevance of the mediating role of language for the development of all complex psychological functions - memory, perception, thought, attention.

Coudry's work ([1986] 1988) aimed, at first, to confront hegemonic aphasiology and speech therapy, especially regarding the methodology of language assessment and therapeutic follow-up. According to the author, the procedures adopted in this tradition derived from a narrow conception of language that reduces its complexity to the linguistic system (the langue); an inadequate and insufficient perspective to account for its social nature.

Franchi (1977), a linguist who fundamentally influenced the field of Discursive Neurolinguistics at the Instituto de Estudos da Linguagem (IEL), described language as a constitutive activity - constitutive of the subjects and of the linguistic system itself. The author reinvigorated the notion of "work" of Marxist philosophies - within the scope of language studies - highlighting the role of subjectivity. According to Franchi, the individuals continuously work on/with the language material resources (phonemes, words, morphemes, grammar rules) in order to produce their discourses (real utterances), in a given social-historicalcultural background. This discursive perspective seems to better account to describe and explain the changes and eventual losses that follow brain lesions and also allows to understand how aphasic individuals develop verbal and/or nonverbal alternative strategies to communicate and to preserve their subjectivity and identity (Coudry, [1986], 1988; Novaes-Pinto, 2012a, b).

To articulate the primary objects of my recent research - the qualitative approach of phenomena addressed in the literature as Word Finding Difficulties (from now on referred to as WFD') - to the scope of Coudry's studies postulated in Diário de Narciso: discurso e afasia, I divide the article into two main parts: (i) The

${ }^{8}$ The name of Leontiev cannot be forgotten when the concept of "activity" is mobilized. His reflections on the theme have generated a whole tradition of studies in Psychology and Education and influenced in a decisive matter the studies of Vygotsky and Luria. These authors worked together in several moments of their academic and professional careers, being referred to as "Troika", the core of socio-historical-cultural approaches

${ }^{9}$ WFD and correlated phenomena have been the main topic of my research since 2004, but they were also addressed in my MA (1992) and Ph.D. research (1999). The works cited along this article about WFD phenomena have been approached, since 2010, in the scope of GELEP - which stands for 'Group of Studies of Language in Aging and in Pathologies' (Lattes Platform/CNPq) of which I am the founder and leader. GELEP engages undergraduate and graduate students of IEL, Unicamp, and has collaborators from several Brazilian institutions, promoting the development of multidisciplinary inquires of linguistic-cognitive phenomena. Most of the works developed within GELEP are linked to the research line Brain, Mind, and Language in our Post-Graduation Program in Linguistics aiming "to stimulate studies dedicated to linguistic processes that relate language, brain, and cognition in the context of aphasia, neurodegenerative processes, and deafness, for instance, as well as the relationship between normal and pathological processes". For more information, see http://www.iel.unicamp.br/ pos/catalogoLL 
theoretical-methodological and ethical principles of Discursive Neurolinguistics and (ii) Discursive analyses of WFD and related phenomena.

\section{THEORETICAL-METHODOLOGICAL AND ETHICAL ISSUES IMPLIED IN THE WORK WITH APHASIC SUBJECTS IN A DISCURSIVE PERSPECTIVE}

The aim of my clinical practice is not the classification of a pathological entity, but, on the contrary, the establishment of relations between language assessment and the process of language reconstruction (Coudry, [1988], 2001, p. 54).

\subsection{Ethical aspects of the work developed with aphasic subjects}

Ethical aspects guide and permeate the first work of Coudry - Diário de Narciso - and all the subsequent research developed in the field ${ }^{10}$. In the very beginning of her doctoral thesis (Coudry, 1986, Preface), the author called our attention to one of her main worries while developing work in aphasiology: to renew clinic practices by adopting different attitudes towards aphasic individuals. In the fragment detached above as an epigraph to this section, she refers to the relations between language assessment and its reconstruction. The aim of her approach, therefore, includes the aphasic individual in the process of his/her language reorganization, which must be seen as: "a joint work, rich of reciprocal experiences, of inter-subjective and personal relationships in which the commitments of complicity are created" (Coudry, [1988] 2001, p. XIII) ${ }^{11}$. These commitments are the ground for the establishment of a profitable relationship between aphasic and non-aphasic subjects.

The methodological procedures developed by Coudry to understand the aphasic's language difficulties will unavoidably encompass therapeutic effects. The author develops "assessment and therapeutic procedures that favor the individual on his way to find what the disease has obliterated and what he (the aphasic) himself underlines" (Coudry, [1988] 2001, p. XIX). Coudry was strongly influenced, regarding these aspects, by the clinical work of Lordat - "in the way Lordat interacted with the aphasics, serving himself from the context and from other non-verbal manifestations, to finally understand them and diagnose them" in dialogical and more symmetrical situations (Coudry, [1988] 2001, p. 43). According to Coudry, Lordat turned the clinic context into a field for the study of language as an effective activity and showed interest for language as a process and not only as a structure (Coudry, [1988], 2001, p. 42).

${ }^{10}$ This assumption does not mean that there are not ethical principles in other theoretical perspectives, but that some relevant differences can be noticed among them. I mention, especially, the roles that both parts - aphasic and non-aphasic subjects - have in the interaction and the work developed at CCA (Centro de Convivência de Afásicos) within community extension projects. Aphasic subjects matter much more than the aphasia itself.

${ }^{11}$ I am using, for this article, the edition of Diário de Narciso published in 2001. 
Inspired by Lyon's words, cited as the epigraph of the next section, we may say that the theoretical-methodological and ethical postulates of Coudry have endured for so long - more than thirty years - because the work developed by researchers and students have decisively changed the lives of hundreds of aphasic subjects that have attended the weekly sessions at CCA.

\subsection{Centro de Convivência de Afásicos (CCA): Locus of research in discursive neurolinguistics}

(...) aphasia treatment should not be a process of a person, but of people. It should not be a process of just language and communication repair, but of facilitating purpose and meaning in life and strengthening ties with others in those natural life contexts that matter the most (Lyon, 1999, p. 689).

CCA was created in 1989, fruit of the partnership between the Institute of Language Studies (IEL/UNICAMP) and the Medical Sciences Faculty (FCM/ UNICAMP), seeking to help aphasic individuals to face the new conditions and limits imposed by aphasia. Following the guidelines posed by Coudry ([1986], 1988), in order to participate in the group, aphasic subjects are neither classified according to etiological or neurological episodes and/or symptoms, nor according to oral or written production/understanding difficulties. We believe that the heterogeneity of cases in the work at CCA enriches our interactions and helps all subjects in the process of language reorganization.

During our CCA meetings, aphasic individuals are encouraged to talk about several themes (their lives and families, national and/or international news that they have read or seen on TV, the results of soccer championships or other sports, politics, etc.). We have started using internet tools many years ago, mainly to read news, search for pictures, videos and songs, according to the subjects' interests. The activities usually involve several speech genres (proverbs, letters, poetry, editorials, charges, autobiographic narrative, fables, jokes, and so on).

We claim that this effective social use of language helps us to understand their linguistic-cognitive difficulties or, in order words, have the role to assess and evaluate language alterations, at the same time that it allows the aphasic individuals along the processes of reorganizing language. Aphasics are recognized as competent subjects who have something to say, despite the limits imposed by aphasia. Through epilinguistic and metalinguistic work on language resources (phonological, lexical-semantic, syntactic, pragmatic-discursive), they develop alternative strategies of signification (Coudry, [1986] 1988) to reach their speechwill (Bakhtin, [1929] 1997).

As afore mentioned, CCA is the locus for our research in the field of Neurolinguistics and also an institutional place to develop community extension programs that have been recognized not only in the Department of Linguistics, but also in the scope of our university, for more than thirty years. ${ }^{12}$

${ }^{12}$ Recently, CCA was headlined by Jornal da Unicamp within a project to promote the community extension activities developed at the university. The article and videos can be accessed at the following link: https://www.unicamp.br/unicamp/ju/noticias/2018/04/18/o-renascer-dos-silenciados (Acesso em 26 de agosto de 2018). 


\subsection{Qualitative approaches in aphasiology and the option for 'case studies'}

Adopting a qualitative methodology, according to Freitas (2010), "is a natural demand posed by socio-cultural approaches to any phenomenon that interests Human Sciences to understand how things happen, rather than just stating that they happen" (Novaes-Pinto, 2012b, p. 223).

Since the works of Jackson (1874) - at the end of the nineteenth century -, according to Damico et al. (1999b), researchers have employed various systematic procedures to obtain both descriptive (qualitative) and numeric (quantitative) data that reflect directly on aphasia approaches. Simmons-Mackie and Damico (1999) suggest that the most relevant difference between quantitative and qualitative methodology is the researcher's immersion in the process, characteristic of qualitative approaches, what gives him the opportunity of taking a learning role and not only a testing role, criticism mentioned in the beginning of this article, regarding the worries that moved Coudry in the process of developing language activities.

In order to highlight how Coudry's proposals were innovative in the end of the 80 's, I will bring to this article some reflections carried out by a very well known group of researchers in contemporary aphasiology, regarding qualitative research. Damico, Oelschlaeger and Simmons-Mackie (1999b, p. 670), for instance, emphasize the importance of collaboration within conversational interactions of "dyads that include an individual with aphasia and an individual without aphasia." Problems created by aphasia, they say, are overcome by the interactants within the dyads, and the adaptive strategies are guided by the conversational principle of sequential organization and aphasics are encouraged "to proceed to self-repair within a collaborative, conversational process, and they often do, which makes it evident that they preserve a communicative competence" (Damico et al., 1999b, p. 673).

Damico and collaborators (Lyon, Simmons-Mackie, Kearns, among others), state that it is not merely the case of discarding quantitative experimental studies, but of accepting their limits. According to them, quantitative/statistical methodology has generated a wide range of scientific knowledge and is certainly an adequate paradigm to approach a vast amount of phenomena. However, when quantitative approaches - created to account for natural phenomena - started being applied to human sciences and to complex psychological functions - such as language, memory or behavior - many reductions were generated, especially because ideal parameters had to be created to represent a state (or a behavior) considered normal. Canguilhem (1985), regarding this issue, affirmed that statistics produce abstract models, while real individuals are usually very far from them.

According to Damico et al. (1999a), under the rubric of "qualitative research" there are a number of traditions of inquiry - bibliographic study, case study, conversation analysis, ethnography, historical methodology, among others that utilize numerous types of naturalistic data collection strategies: observation, interviewing, text analysis, etc. Qualitative research, therefore, may be seen as an analytic paradigm, a set of systematic and interpretative practices "designed 
to seek answers to questions that stress how social actions and social experiences are created and sustained" (Damico, Simmons-Mackie, Oelschlaeger, Elman and Armstrong, 1999a, p. 652). The authors claim that it is a sophisticated and complex methodology, with a long and well-established history and it aims to consider the social handicapping conditions of neurological impairment and to employ additional research methodologies to obtain more authentic, functional and naturalistic data on aphasia.

Another important issue of qualitative approaches is that the research design "unfolds as data are collected and analyzed resulting in a cyclical and flexible process" (Simmons-Mackie and Damico, 1999, p. 687). According to the authors, "the investigator collects, analyzes and verifies data, identifies phenomena of interest, then continues to collect and analyze data to progressively narrow the investigation and hone in on phenomena of interest" (...) and, thus, "seeks to discover whatever emerges as important to the understanding of the phenomenon under study".

Unusual, repeated or patterned events or behaviors can often provide a focal point for narrowing investigation; unexpected events or observations often provide a window into the phenomenon of interest. According to Simmons-Mackie and Damico (1999), the contrast between expectations and observations is one means of discovering new insights and exposing researcher biases and beliefs. In another article, Damico et al. (1999a) see this flexibility as a need for qualitative research, which includes the ability to shift the methods of data collection even after the analysis have started.

Concerning these aspects, there is a relevant concept postulated by Coudry (1996), which was synthesized in the expression "dado-achado", a neologism in Portuguese and difficult to be translated. Perhaps the most appropriated term in English would be "a found-data", in the sense that the data is discovered (found) through a heuristic process developed by the researcher, in the process of researching. This kind of data would neither be evident in itself, nor a mere illustration of a phenomenon or of a theory. It promotes, instead, a movement in theory; it feeds theory, transforms it and challenges the researcher towards discoveries. According to Coudry (1996, p. 184), "if the data is constructed in interaction, a bond is built between the investigator and the patient, which is relevant either for the emergence of the data itself as well as for the therapeutic process".

Another relevant issue regarding qualitative approaches to aphasia is the choice for 'single-case' studies, which have helped to build and solidify the neurolinguistic and neuropsychological theories. According to Miceli (2001, p. 658), "much of the theoretical progress in the Neurology and Neuropsychology of aphasia results from the detailed study of individual aphasic subjects." Case studies have proved to be "a powerful heuristic tool in cognitive Neurology/ Neuropsychology, and with time they have provided an impressive body of evidence, demonstrating the complex architecture of the linguistic system". Kearns (1999) believes that single subject methodologies are now widely accepted as a legitimate tool to investigate clinically relevant questions about aphasia. The 
author emphasizes this issue stating that: "many valuable lessons were learned as researchers favoring single subject designs worked towards full acceptance into the scientific community" (Kearns, 1999, p. 649). Still regarding the choice for case studies, Gil (1995) emphasizes the context of the investigation, its specific and well-delimited aspects considering time and place. For André (1984), case studies may present different perspectives, once they intend to answer questions that quantitative approaches cannot. In her words,

Case studies reveal vicarious experience and allow naturalistic generalizations, from the scope of the individual and in function of their experiential knowledge [...]. They seek to portray reality entirely and profoundly, intending to reveal the multiplicity of dimensions present in a given situation, focusing on it as a whole, while emphasizing the details, the specific circumstances that favor a greater apprehension of this whole (André, 1984, p.52).

According to Stake (2000 apud Boccato, 2018, p. 12), a single case is valid because "it corroborates significant theoretical propositions and reveals questions about a phenomenon under investigation, generating access to information that would not be available without a closer look." The author argues that generalizations arising from a single case, studied in depth, are more reliable than those derived from quantitative studies since a single case can provide a circumstantial and, therefore, more precise elucidation of the conditions in which phenomena occur.

It is relevant to remember and emphasize that Coudry ([1986] 1988) privileged case studies and qualitative research. Her method was based in the use of diaries, family albums, activity notebooks, interaction with family members always considering the interests shown by the aphasics.

Regarding the questions posed by Neurolinguistics - more centrally the relation between brain and language -, it should be considered that, although statistical correlations can be established between a symptom or a syndrome (a set of symptoms) and a specific neural area or structure, the causal correlations might not explain the processes underlying a phenomenon. Therefore, they do not provide clues for the reorganization of language in therapeutic follow-ups. Dialogical evaluations necessarily demand to consider variables such as: who the speakers are, their social classes and roles, inferences and shared-knowledge between the parts, the discursive topics and speech genres, levels of formality, and so on. These factors enable us to understand how the brain damage disturbed language functioning, as well as other cognitive domains, which are mediated and constituted by linguistic processes (Novaes-Pinto, 2012a, b).

Coudry criticizes most of the psychometric tests used by researchers to establish models, but mainly those elaborated for clinical purposes: tests formulated within artificial situations focusing on isolated units of the language system (phonemes, words, sentences, letters, syllables, etc.); tasks that are wholly decontextualized from social use and apart from the subject's personal history. The relationship between the investigator/clinician and the aphasic subject in these approaches is always asymmetrical. According to the author, "the success or failure of the aphasic individual in one or more of those tests serves as criteria to classify him/her into a type of aphasia" (Coudry [1988], 2001, p. 9). Tasks like naming, defining, listing, 
repeating, etc. exclude the individuals from interlocution processes; the artificial situation "is build up from the point of view of the examiner, even if it appears to be an appeal to the aphasic to speak" (Coudry [1988], 2001, p. 11).

Coudry considers that metalinguistic tasks might help to establish a diagnosis, but cannot replace linguistic and epilinguistic activities. The author also mentions that the exercises are guided by the written structures of language and strongly committed to a scholar view, "in the worst sense of "scholar"' (Coudry [1988] 2001, p. 6). She considers that the most serious consequence of this approach is that the assessment tests, on one hand, deprive the subjects of epilinguistic activities that are essential to the construction and reconstruction of language and, on the other hand, deprives the researcher of understanding the singular and personal course of each subject in his/her work with/on language. In other words, this approach inhibits the linguistic work that allows the subject to "elaborate hypothesis about the structure of language or specific forms of its use" (Coudry [1988], 2001, p. 15).

Taking these facts altogether, Coudry concludes that empirical results that derive from statistical analysis of metalinguistic tests - reduce the language complexity, are too restricted to understand the linguistic difficulties of aphasic individuals, and, therefore, to provide subsidies for the therapeutic follow-up (Coudry, [1986], 1988; Coudry and Novaes-Pinto, 1994). Social interactions are, according to her, the best locus to evaluate how aphasic subjects reorganize language and develop "alternative strategies of signification" despite the type of aphasia he/she has and how severe the impairment is. In other words, this methodology allows the researcher to establish hypothesis about the underlying linguistic-cognitive processes that have to be taken into account to understand aphasia phenomena and help the subjects in their way to signification.

In the next section, I will bring and analyze some data from Coudry's Diário de Narciso and also from research produced in the scope of GELEP, in order to argue that the studies of WFD phenomena, from a qualitative perspective that privileges dialogical contexts, allow a better understanding of lexical-semantic organization and functioning and, thus, promotes advances in linguistic and neurolinguistic theories.

\section{WORD FINDING DIFFICULTIES AND THE ORGANIZATION OF SEMANTIC-LEXICAL UNITS}

Word Finding Difficulties (WFD) is a broad and generic term in the aphasia semiology used to refer to different phenomena that occur along the course of communication acts ${ }^{13}$, which may range from the complete absence of a name ${ }^{14}$

${ }^{13}$ Although alluding mostly to the difficulties that arise in pathologies, the WFD phenomena also emerge in spontaneous and quotidian speech. The difference between these states is, according to Luria (1986), their rate of occurrence - much higher in pathological conditions, especially in aphasia.

${ }^{14}$ When a target (desired) word doesn't come, as just mentioned, the phenomenon is known as anomia - a term which, in our point of view, does not correspond to the fact. Some theories favor an argument that the word has been lost in the subject's mental lexicon. However, the same word that 
to the occurrence of several paraphasias (Novaes-Pinto, 2009, 2013; NovaesPinto and Souza-Cruz, 2012, Souza-Cruz 2014, 2017). In the neuropsychological literature, WFD refer mostly to open class words (nouns, verbs, adjectives and adverbs), assessed through naming tests. Closed class lexicon - mainly inflectional morphology and functional words, present in the production of the socalled "telegraphic speech" - have also been approached in its relation to WFD, as firstly pointed by Coudry ([1986] 1988) $)^{15}$ and brought back by more recent works (Novaes-Pinto, 1992, 1999; Lima, 2017; Lima \& Novaes-Pinto, 2017).

It is possible to observe WFD and related phenomena - such as the production of literal and semantic paraphasias, TOTs ${ }^{16}$, frequent repetitions, hesitations, the telegraphic style utterances, perseverations, circumlocutions, among others - in different kinds of aphasia and varying in frequency according to different severity degrees. Mazuchelli $(2017,2018)$ has also related the occurrence of WFD within normal and pathological aging processes.

Considering that Luria grounded most of his reflections about language functioning on Jakobson's theory - also referred by Coudry since her first work -, I point out some of this author's concepts, which will be useful for the data analysis presented in the next section.

Jakobson (1954) provided linguistic explanations for aphasia and, based on the operations postulated by Saussure (1916), proposed a terminology in terms of selection and combination of linguistic units, seeking to explain the main difficulties observed in the two paradigmatic types of aphasia: agrammatism and jargonaphasia. The former would occur due to the aphasic's problems to operate with the combination and contexture of linguistic units - on the syntagmatic axis -, difficulties to combine phonemes within the context of morphemes, morphemes within the scope of words, words to form a sentence and also to combine sentences to compose what he calls "discourse" or "text". This model could explain, for instance, the production of telegraphic style utterances (Lima, 2017), as we will see ahead, when presenting and analyzing the data of subject $\mathbf{P}^{17}$. In the paradigmatic/ associative axis, the difficulties would be rather due to the inadequate selection of a specific unit among other similar ones - as in the data of $\mathbf{J M}-$, which would account for the vast quantity of paraphasias and which leads, in the most severe cases, to a jargonaphasia.

sometimes does not arise in a certain context will appear in another. This issue has also been addressed by Coudry ([1986], 1988) who, in turn, mentioned Jackson (1874) and other classical aphasiologists. Other argument against the idea of loss of the word in a mental lexicon is the subjects' ability to point to a picture from its name.

${ }^{15}$ We hope, with our research, to account for WFD not only in aphasia, but also in other brain pathologies that impact language. I mention, among others, the works developed by Beilke (2010) on Alzheimer, Algave (2012) on epilepsies, Mazuchelli (2013) on Progressive Aphasia and Camillo (2017) on Parkinson Disease.

${ }^{16}$ Tip-of-the-tongue phenomenon, which will be approached later in the article.

${ }^{17} \mathbf{P}$ was one of Coudry's aphasic subjects along her doctoral research. He had a very severe expression aphasia (also known as Broca aphasia) and could be considered, according to classical semiology, as a typical case of agrammatism. 
Jakobson recognizes, however, that most of the "real cases" would be placed along the line that links the two extreme ends of the axes. His model, therefore, cannot be understood as static. On the contrary, it has to be interpreted as dynamic because the two operations are interdependent ${ }^{18}$. The author's explanation for aphasia has been helpful for research in the field of Discursive Neurolinguistics, mainly because it provides an alternative to classical aphasia classifications and overcomes many inadequate dichotomies to account for the complex linguistic processes.

\subsection{Agrammatism and telegraphic speech: the original contribution of Coudry's work}

Aiming to illustrate the dialogical processes that Coudry established with aphasic subjects, on the one hand, and to emphasize how this methodology contributes to the theoretical advances in Neurolinguistics, on the other, I bring some dialogical episodes analyzed by the author in Diário de Narciso. They were chosen for being more related to the phenomena of interest in this article - Word Finding Difficulties.

Agrammatism is one of the leading research themes in Neurolinguistics, mainly because it is believed to reveal the syntactic nature of underlying language disturbances in non-fluent aphasia, especially in the production of the so-called "telegraphic speech" (Novaes-Pinto, 1992, 1997, 1999). The ungrammatical production would be generated due to the loss of the closed class mental lexicon or to the subject's difficulties to operate with free and bound morphemes (Tissot, Mounin and Lhermitte, 1973; Grodzinsky, 1984; Goodglass, 1976; among others). Coudry ([1986], 1988) argued that such hypothesis only partially explains the subject's difficulties and she provided qualitative explanations for both the production of telegraphic style speech and also for the fact that the same aphasic subject sometimes produces functional words and sometimes does not.

In Diário de Narciso, the author approached the case of $\mathbf{P}$, calling attention to the work he accomplished to produce meaning, along interactions. Of all the data gathered by Coudry ([1986], 1988), I selected a few to illustrate the WFD phenomena that, from my point of view, discloses the theoretical-methodological principles described so far in this article.

Each dialogical episode is a singular ${ }^{19}$ one, a privileged locus to convey meaning in close collaboration with the aphasic individuals, as we will see in the conversations that follow.

\footnotetext{
${ }^{18}$ Concerning this matter, Coudry (2002) stated that each of the axels have a projection on the other.

${ }^{19}$ In the sense given by Abaurre (1996), the singular data is the one that may promote advances in the theories, the data that question theoretical "established truths" and give visibility to processes underlying a phenomenon.
} 
In Episode 1, Coudry was showing $\mathbf{P}$ a picture of a car stopped by a gas pump, in a gas station ${ }^{20}$. There was a man cleaning the car windshield with a tissue $^{21}$.

Episode 1: Piando, limando, limpando ${ }^{22}$

\begin{tabular}{|c|c|c|}
\hline $\begin{array}{l}\text { Dialogical } \\
\text { Turns }\end{array}$ & $\begin{array}{c}\text { Utterances } \\
\text { P: Aphasic subject; Imc: } \\
\text { Investigator }\end{array}$ & $\begin{array}{c}\text { Comments about Non-Verbal } \\
\text { Utterances }\end{array}$ \\
\hline Imc & What is this man doing with the car? & Showing him the picture. \\
\hline $\mathbf{P}$ & Gasoline. & \\
\hline Imc & But he is not filling with gasoline! & \\
\hline $\mathbf{P}$ & Glasses, right? & \\
\hline $\operatorname{Imc}$ & There is only one glass there, right? & $\begin{array}{l}\text { Imc calls his attention for the details } \\
\text { in the picture. }\end{array}$ \\
\hline $\mathbf{P}$ & It is $[\ldots]$ glasses. & \\
\hline $\operatorname{Imc}$ & And what is he doing? & \\
\hline $\mathbf{P}$ & Dust, dusts ${ }^{23}$. & $\begin{array}{l}\text { P makes a circular gesture with his } \\
\text { hands, representing the action of } \\
\text { cleaning the glass with a tissue. }\end{array}$ \\
\hline Imc & What is he doing? & \\
\hline $\mathbf{P}$ & {$[\ldots]$} & \\
\hline
\end{tabular}

${ }^{20}$ In the transcription, Imc stands for "Investigator" followed by two initial letters (usually the first and the last) taken from the researcher's name: Maza Coudry. "P" is the letter that refers, in Coudry's work, to the aphasic subject. The sign "[...]" is used to mark long pauses. Notes were taken by the researcher, along the dialogic process, and are written between parentheses in the third column.

${ }^{21}$ It is very difficult to translate aphasia data from one language into another. For this reason, some translation comments are inserted in footnotes. The dialogical episode was reported by Coudry ([1986] 1988, p. 136-137).

${ }^{22}$ In Portuguese, the verbal form of "cleaning" is "limpando". The investigator gave $\mathbf{P}$ the first syllable of the word: $\lim . .$. . As he did not produce it, she extended the prompting to limpan.... In the translation, I tried to keep the phonological similarities produced by $\mathrm{P}$ in Portuguese (piando, limando, limpando), which might have guided his search for the word. In this specific case, it seems he was not guided by semantic links. This is the reason why I have not translated into English the same verbs he used in Portuguese: "piando" and "limando", which means in English: "chirping" and "filing".

${ }^{23}$ It is important to say that in Portuguese "dust" is "poeira" (which is not usually used in plural) and there is not a homonymous verb "poeirar", like in English dust (noun) and to dust (verb). "To dust", in Portuguese, is "tirar o pó"- take the dust off. 


\begin{tabular}{|c|l|l|}
\hline \hline Imc & What is he doing?:sep? & $\begin{array}{l}\text { Imc repeats the question } \\
\text { emphasizing the verb. }\end{array}$ \\
\hline $\mathbf{P}$ & This... & $\begin{array}{l}\text { Prepeats the gesture of cleaning the } \\
\text { glass. }\end{array}$ \\
\hline Imc & What is he doing? & $\begin{array}{l}\text { Imc emphasizes the verb in order to } \\
\text { elicit the right inflectional form. }\end{array}$ \\
\hline $\mathbf{P}$ & Dust... dusts. & $\begin{array}{l}\text { P makes again the circular gesture, } \\
\text { representing the action of cleaning } \\
\text { the glass. }\end{array}$ \\
\hline Imc & Right. Get a tissue and dusts it. & \\
\hline $\mathbf{P}$ & Right. Right. & $\begin{array}{l}\text { The investigator gives him a } \\
\text { prompting for "cleaning". }\end{array}$ \\
\hline Imc & Clea... & Imc extends the prompting. \\
\hline $\mathbf{P}$ & {$[\ldots]$} & \\
\hline Imc & Clean... & Peeling... clicking... cleaning! \\
\hline $\mathbf{P}$ & & \\
\hline & & \\
\hline
\end{tabular}

The aphasic subject's utterances, as we may observe, were predominantly produced in a telegraphic style24. $\mathbf{P}$ mainly produced nouns in order to describe the action represented in the picture - gasoline, glasse(s), dust $(s)$ - even when Imc asked him what he was doing. As she insisted on the question, he finally produced "cleaning." This strategy used by Coudry demanded that P worked on the language resources still preserved, in order to produce meaning. However, more important than producing the target word - cleaning - was the fact that P gave Imc many clues about his attempts for selecting it, revealing the underlying processes as he produced peeling, clicking and, finally, cleaning (Novaes-Pinto, 2012).

Coudry ([1986] 1988) had already suggested that the morpheme /s/ in P's utterances did not correspond to a plural form. Instead, she interpreted its presence as a sign of the subject's instability and difficulty to select words (Novaes-Pinto, 2012). The phenomenon is also present in other utterances (nouns and verbs), as follows: $:^{25}$

(i) Imc: What is the maid doing? (Picture of a woman cooking) P: Soups

(ii) Imc: What are these people doing? (Picture of people shopping) P: Stores

${ }^{24}$ Novaes-Pinto $(1992,1999)$ had suggested the expression "telegraphic style speech", while Lima (2017) proposed the term "telegraphic style utterance" in order to be more coherent with the social-cultural approaches and with the bakhtinian theory that establishes "utterances" as the real units of verbal communication.

${ }^{25}$ Utterances (i), (ii) and (iii) correspond to data 17, 31 and 46 on Diário de Narciso: discurso e afasia (Coudry [1988] 2001, p. 98, 103 and 116, respectively). Data (iv) corresponds to Coudry's episode number 34 (Coudry [1988] 2001, p. 105). 
(iii) Imc: What are those men doing? (Picture of two man on a boat)

P: Rivers, rivers

(iv) P: Men (while he was looking at a picture of a man riding a horse, jumping over some obstacles).

Imc: What is he doing?26 (While pointing at the horse)

P: Jumps. Horses.

Another very interesting episode to illustrate the attempts of $\mathbf{P}$ to adequately select the inflectional morpheme of a word is when he was asked about what some girls were doing, while looking at a picture 27.

(v) Imc: What are they doing?

P: Sambanho, samban... [...] What is the name?

Imc: Samban... (prompting for "sambando").

P: Sambanha, sambanhas, Sambanhas.

Imc: Samband... (extending the previous prompting)

P: Sambando!

P firstly produced a paraphasic word - sambanho - mixing the target word (sambando) with the inflection for the $1^{\text {st }}$ person singular form (in Portuguese "eu sambo"/I dance samba). After that, he corrected himself producing samban. After a short pause, he produced a crystallized and very recurrent form in aphasia: "What is the name?", which might have given him some extra time to achieve the word. It is interesting to notice his attempts to find the exact word within the verbal paradigm. On his attempts, he produced sambanha (3rd person singular: "ela samba"/she dances samba) and then he said sambanhas (2nd person singular: "tu sambas"/you dance samba). Only after another extended prompting given by the investigator (samband...), he produced the right verbal form: sambando (dancing samba), which adequately answered the question posed by Coudry: What are they doing? It is worth noting that the collaborative process was crucial for him to reorganize his utterance.

This dialogical episode helps us better understand WFD in the context of aphasia and allow us to question traditional views of agrammatism, in which difficulties are usually explained as the loss of the functional words and of the verbal inflections (Novaes-Pinto (1999, 2009, 2012b, 2013; Lima, 2017; Lima \& Novaes-Pinto, 2017).

${ }^{26}$ In Portuguese, the word "homem" (for horse) has the plural homens, which was the actual production of $\mathrm{P}$, maintaining his tendency to produce nominal forms with "s". While in English, jumps would be the right inflection for the third person singular, in Portuguese pulas does not correspond to the grammatical form.

${ }^{27}$ The dialogical episode corresponds to number 59 of Coudry's work (2001, p. 125). 


\subsection{Production of paraphasias and paralexias: evidences about lexical- semantic organization and functioning}

Luria (1986) says, regarding lexical features and links, that not only does a word generate the indication of a given object (the referential function) but also, inevitably, leads to the appearance of a series of additional links, including elements that are somehow similar. The word "garden" can involuntarily evoke, for instance, the words trees, flowers, bench, meeting or even potato, onion, shovel, etc. In his approach, the word becomes a "central node" of a whole network of images, evoked connotatively. One who speaks or listens to a word inhibits this whole network of images to choose the immediate or denotative meaning (Luria, 1986). According to the author, the semantic field is shown with all evidence in the phenomenon widely known in the literature as WFD, which occurs in all types of aphasia. One of the most interesting phenomena related to WFD is the presence of paraphasia, which also occurs in non-aphasic production, but significantly higher in frequency in aphasia.

Regarding these phenomena, Novaes-Pinto (2012) states that:

It is possible (...) to understand phenomena as word finding difficulties, production of paraphasias (literal or semantics), frequent repetitions and pauses, telegraphic speech style, perseverations, among others, in different kinds of aphasia and different severity degrees, from the perspective of language functioning, along the process of producing or understanding it. It also allows us to have a glimpse of how linguistic difficulties could be related to other functional processes as attention, memory, perception, logical thinking, problem-solving, etc. All these variables are present, at the same time, when language is used in communication contexts (Novaes-Pinto, 2012, p. 18).

Aiming to point out the process of word selection by an aphasic subject $-\mathbf{J M}$ -, I present Episode 2, in which the semantic field is shown, as said by Luria, with all of its evidence.

Episode 2: Em briga de marido e mulher... ${ }^{28}$

\begin{tabular}{|l|l|l|l|}
\hline $\begin{array}{c}\text { Dialogical } \\
\text { Turns }\end{array}$ & Participants & \multicolumn{1}{|c|}{$\begin{array}{c}\text { Utterances } \\
\text { JM: Aphasic subject; Irn: } \\
\text { Investigator }\end{array}$} & $\begin{array}{c}\text { Comments about } \\
\text { Non-Verbal } \\
\text { Utterances and } \\
\text { translations }\end{array}$ \\
\hline $\mathbf{1}$ & Irn & $\begin{array}{l}\text { Em briga de marido e mulher... } \\
\text { Ninguém... Ninguém mete a... } \\
\text { Please, make that gesture for me... } \\
\text { Of the object that completes the } \\
\text { proverb... } \\
\text { Ninguém mete... }\end{array}$ & $\begin{array}{l}\text { Irn shows JM the } \\
\text { first part of the } \\
\text { proverb written in a } \\
\text { card: "Em briga de } \\
\text { marido e mulher" }\end{array}$ \\
\hline
\end{tabular}

${ }^{28}$ The proverb corresponds in English to "In a quarrel between a husband and his wife, keep away." Literally, in Portuguese, the proverb means: "In a quarrel between a husband and a wife, nobody puts the spoon." 


\begin{tabular}{|c|c|c|c|}
\hline 2 & $\mathbf{J M}$ & Drinking coffee... & $\begin{array}{l}\text { Irn makes the } \\
\text { gesture of "stirring } \\
\text { something", in order } \\
\text { to elicit the word } \\
\text { "colher" (spoon). } \\
\text { When he says } \\
\text { "Drinking coffee", } \\
\text { everyone in the room } \\
\text { laughs. }\end{array}$ \\
\hline 3 & Irn & $\begin{array}{l}\text { Drinking coffee? We sometimes } \\
\text { use it to drink coffee. What is it? A } \\
\text { knife? }\end{array}$ & Laughing \\
\hline 4 & $\mathbf{J M}$ & No:: & \\
\hline 5 & Irn & $\begin{array}{l}\text { What is it? Look... It has got to } \\
\text { rhyme. } \\
\text { 29،"Em briga de marido e mulher, } \\
\text { ninguém mete a ...". }\end{array}$ & \\
\hline 6 & $\mathbf{J M}$ & Refe... ga:: fo::: & $\begin{array}{l}\text { JM produces the first } \\
\text { syllable of the word } \\
\text { "refeição" (meal) } \\
\text { and then the word } \\
\text { "garfo" (fork) }\end{array}$ \\
\hline 7 & Irn & Fork? It is not the fork! & \\
\hline 8 & $\mathbf{J M}$ & É... mai:: lá:: & $\begin{array}{l}\text { JM makes a gesture } \\
\text { with his hand, } \\
\text { indicating "so so" }\end{array}$ \\
\hline 9 & Irn & What do we use to have soup? & \\
\hline 10 & JM & What? & \\
\hline 11 & Irn & What do we use to have soup? & \\
\hline 12 & $\mathbf{J M}$ & Gar... é:: co... & $\begin{array}{l}\text { JM hesitates while } \\
\text { he tries to retrieve } \\
\text { the word "colher". }\end{array}$ \\
\hline 13 & Irn & $\begin{array}{l}\text { "Colher... em briga de marido e } \\
\text { mulher, ninguém mete a..." }\end{array}$ & $\begin{array}{l}\text { Irn reads the proverb, } \\
\text { leaving the last word } \\
\text { to be completed. }\end{array}$ \\
\hline 14 & $\mathbf{J M}$ & Colher! & $\begin{array}{l}\text { JM produces the } \\
\text { correct word. }\end{array}$ \\
\hline 15 & Irn & Colher... & Smiling to JM. \\
\hline 16 & $\mathbf{J M}$ & This one I... & $\begin{array}{l}\text { Points to himself and } \\
\text { shakes his head. }\end{array}$ \\
\hline
\end{tabular}

${ }^{29}$ In Portuguese the word "mulher" (woman; wife) rhymes with "colher" (spoon). 
This episode was first analyzed by Novaes-Pinto and Souza-Cruz (2012). Similarly to the data of subject $\mathbf{P}$, we argue that this interaction with $\mathbf{J M}$ is also singular, once it allows us to follow the course of the aphasic subject along the process of selecting and producing the target-word "colher", in order to complete the proverb.

We notice, in Turn 1, that $\mathbf{J M}$ refers (with a gesture) to a specific feature an attribute of the object (spoon serves to stir liquid), while trying to name it. It seems that his gesture favored, in Turn 2, the production of his verbal utterance: "drinking coffee" ${ }^{30}$. JM kept trying to produce the target word and, in Turn 6, produced "garfo" (fork). Before that, however, he started producing "refe:", which we interpret as the beginning of the word "refeição" (meal).

Only in Turn 13, after reading the word "colher" on another card, JM was able to produce it. The lexical chain "refeição," "garfo," and "colher" shares category features and may illustrate the role of semantic links during the process of retrieving a word. It is necessary to consider that the qualitative approach and more specifically the dialogical methodology were fundamental to the emergence of those links, even if triggered by a metalinguistic task (the work with proverbs).

Also aiming to illustrate the enlaces pointed by Luria (1986), I bring some data from Boccato (2018), related to the production of paralexia, a phenomenon correlated to paraphasia, but that occurs specifically in the context of reading. In the first column, there are some of the words presented in several texts read by BS; in the second column are shown the words produced by the subject ${ }^{31}$ while reading.

Table 1: Paralexias produced by BS

\begin{tabular}{|c|c|}
\hline Target-Words (written in the text) & Words effectively produced \\
\hline Meses (Months) & Anos (Years) \\
\hline Primogênito (Firstborn) & Patriarca (Patriarch) \\
\hline Alienígenas (Alien) & Extraterrestres (Extraterrestrial) \\
\hline Ato (Act) & Gesto (Gesture) \\
\hline Cuidado (Care) & Trabalho (Work) \\
\hline Viagem (Trip) & Jornadas (Journeys) \\
\hline Perfume (Perfume) & Fragrância (Fragance) \\
\hline Fora (Out) & Dentro (In) \\
\hline Principal (Main) & Primordial (Primordial) \\
\hline Horror (Horror) & Odor (Odor) \\
\hline
\end{tabular}

${ }^{30}$ Data like this led Coudry (2008) to adopt the concept of "translation" in the context of aphasia. The aphasic subject develops alternative strategies of signification, translating verbal forms to nonverbal signs and vice-versa.

${ }^{31} \mathrm{BS}$ is a young aphasic individual that attends CCA. All reading activities were developed dialogically with him. 


\begin{tabular}{|c|c|}
\hline Terríveis (Terrible) & Horríveis (Horrible) \\
\hline Menos (Less) & Mais (More) \\
\hline Vários (Several) & Muitos (Many) \\
\hline Quando (When) & Onde (Where) \\
\hline Quando (When $)$ & Quanto (How much) \\
\hline Como (How) & Quando $($ When $)$ \\
\hline
\end{tabular}

The phenomenon of paralexia brings up the same sort of questions as paraphasia, but it is peculiar in the sense that the investigator has a greater degree of confidence about the relationship between the "target word" (which is written in the text) and the produced one, in the context of reading aloud (Boccato, 2018; Souza-Cruz and Boccato, 2017).

According to Boccato (2018), besides semantic associations (months/years; out/in; less/more; trip/journey; perfume/fragrance, etc) and phonological links (horror/odor) between the target and the produced words, it is possible to notice that substitutions also occur within closed classes, such as pronouns (when/where; how/when, etc) and prepositions (out/in). The study of paralexia is, certainly, a topic to be further investigated ${ }^{32}$ in the context of Discursive Neurolinguistics and may contribute in a very relevant way to the development of hypotheses on lexical-semantic functioning.

\subsection{The Tip-of-the-Tongue (TOT) phenomenon}

Back in 1890, William James described the sensation that occurs when someone "seeks" for a word that does not come, accompanied by the feeling of knowing the target word. This phenomenon is known as TOT (Tip-of-TheTongue) and has been mainly studied through quantitative methods (Oliveira, [2015]/ 2017) ${ }^{33}$.

Oliveira approached the phenomenon qualitatively, grounded on a socialcultural perspective and, mainly, on Discursive Neurolinguistics. In the following dialogue $^{34}$ reported by the author, we may observe the occurrence of WFD that arises in the form of a TOT.

Episode 3: Fidel and Che Guevara.

\begin{tabular}{|c|l|}
\hline Interlocutors & \multicolumn{1}{|c|}{ Utterances } \\
& SB: Aphasic subject ;mo: investigator \\
\hline SB & You look like that man... That man is... That man with a beard. \\
\hline
\end{tabular}

${ }^{32}$ For more details and examples, refer to Boccato, 2018.

${ }^{33}$ Oliveira's doctoral thesis is from 2015. In 2017, it was published with the same title, as a book, by Pedro \& João Editores.

${ }^{34}$ SB corresponds to the aphasic individual's initials, while Imo refers to the initials of the researcher, who is also a speech therapist. 


\begin{tabular}{|c|l|}
\hline \hline Imo & Who? That musician? \\
\hline SB & $\begin{array}{l}\text { No! It's another one... It's almost here... Okay ... Here it is... } \\
\text { That... You know? There... You know, right? I'll say the one I } \\
\text { know and then you will know what I don 't know. }\end{array}$ \\
\hline Imo & Say it! \\
\hline SB & Fi...del Castro. \\
\hline Imo & Oh! I look like Che Guevara? What nonsense! \\
\hline SB & That! Yes! \\
\hline
\end{tabular}

We may suppose that SB not only knew who Fidel Castro and Che Guevara were, but also counted on the fact that Imo would be able to relate those names. Although she was not able to name "Che Guevara," she explicitly mentioned that the word was at the tip-of-her tongue when she said (in Turn 3): "It's almost here" (and pointed to her tongue). Besides the fact that Imo and Fidel Castro wore a beard, she knew that all of them - Fidel Castro, Che Guevara and Imo - shared similar ideological positions.

SB used a successful strategy to lead Imo to the name she wanted to find, especially after she said: "I'll say the one I know and then you will know what I don't know". Oliveira (2015) analyses this episode and other similar data aiming to approach the relationship between memory and language, as well as the relevance of shared-knowledge and inferences to convey meaning in conversation. Especially in cases of aphasia, as Coudry ([1986], 1988) had shown, such dynamism and collaboration are fundamental to help the aphasic individuals to reach their speech-will (Bakhtin [1929] 1997; Novaes-Pinto, 1999).

\subsection{Linguistic competence in "normal" 35 and pathological aging: evidences from WFD studies}

Since the beginning of the research developed within GELEP, there has been a special interest for language phenomena in aging processes - in pathological and in normal conditions. Novaes-Pinto (2008) called attention for the exclusion suffered by elder subjects based, among other motivations, on linguistic features. The author mentioned the lack of linguistic studies on this topic and cited Preti (1991) - A linguagem dos idosos ${ }^{36}$ - as the only text in Brazilian Linguistics to approach it by then. Novaes-Pinto questioned some of the conclusions taken by Preti $(1991)^{37}$ and pointed out the need to deepen the linguistic studies in this field $^{38}$.

\footnotetext{
${ }^{35}$ We use "normal" in the sense of "non-pathological" states.

${ }^{36}$ The Language of the elderly.

${ }^{37}$ Preti (1991) based all his reflection on data taken from one single interview with a literate subject, in the context of NURC Project (Norma Urbana Culta; Literate Urban Linguistic Norm) and on foreign literature about the subject.

${ }^{38}$ I have published with Oliveira some articles addressing the relationship of language and memory in normal and pathological aging. Regarding this matter, see Novaes-Pinto e Oliveira (2014).
} 
According to Burke and Shafto (2004 apud Mazuchelli, 2017), WFD phenomena would be responsible for most of the aging people's complaints regarding language. The authors, indeed, consider the process of "finding" and producing words as one of the cognitive domains most affected by aging and believe that aging weakens connections among linguistic representations. Senescent individuals would be more susceptible to find themselves in a tip-of-the-tongue state, for example, what would, in turn, lead them to hesitation, frequent discourse interruptions, etc. It is frequent in the literature that all of these "symptoms" are attributed to a memory failure or age-related atrophies in certain areas of the brain.

Shafto, Burke, Stamatakis, Tam and Tyler (2007), for instance, suggest that the rise of word-finding failures and the increasing occurrence of TOTs could be explained by such age-related atrophy in neural regions essential for phonological production. From our point of view, however, although they might be related, the attempt to explain WFD or TOTs as a problem of phonological production is very reductionist.

Mazuchelli (2018) has approached language in aging processes in order to demystify some of these current ideas and stereotypes. Instead of understanding WFD, for instance, as a mere "symptom" of aging - connected with other assumed linguistic characteristics of this population - as verbosity, prolixity or redundancy - , a linguistic analysis of what appears when the word "does not come" (pauses, paraphasias, TOTs, auto-correction, reorganizations) may imply pragmaticdiscursive competence. The production of circumlocutions, for instance, as the author points, may be understood as a strategy developed by speakers to deal with the complexity of verbal communication, either in normal or in pathological conditions.

According to Mazuchelli (2017), the reason why only the difficulties are highlighted in most studies derives from the fact that language is investigated in experimental approaches that seek to control the communicative context and the variables that may act in the production of the individuals. The author develops qualitative research based on interviews with aging individuals, in which the conversation topics which are meaningful to the subjects, about their everyday routines and affairs, family, politics, sports and so on, following the theoreticalmethodological and ethical issues of Discursive Neurolinguistics, as initially postulated by Coudry.

In the following dialogue, for instance, Catarina, one of the subjects Mazuchelli interviewed for her research, while facing WFD, provides precise clues of the word she's trying to select:

Episode 4: Ferrari

\begin{tabular}{|l|l|}
\hline \multicolumn{1}{|c|}{ Interlocutors } & \multicolumn{1}{c|}{$\begin{array}{c}\text { Utterances } \\
\text { Catarina: } \text { Aged subject } ; \text { Ilm: Investigator }\end{array}$} \\
\hline$\underline{\mathrm{Ilm}:}$ & Your grandson, right? \\
\hline Catarina: & My oldest grandson. \\
\hline
\end{tabular}




\begin{tabular}{|l|l|}
\hline$\underline{\text { Ilm: }}$ & Oh, ok. \\
\hline Catarina: & $\begin{array}{l}\text { And... he asked for a leave permission this week to got } \\
\text { there to Italy. Now he is... working doubled... but he } \\
\text { will... he will work for a while because he was invited to } \\
\text { stay in Bologna. }\end{array}$ \\
\hline$\underline{\text { Ilm: }}$ & To study? \\
\hline Catarina: & $\begin{array}{l}\text { To do research at... at... the lab of... oh... of these } \\
\text { racing cars... Very famous... I don't remember the } \\
\text { name. }\end{array}$ \\
\hline$\underline{\text { Ilm: }}$ & Ferrari? \\
\hline Catarina: & Ferrari! \\
\hline
\end{tabular}

Although many subjects, as Catarina, refer to WFD as a memory failure: $I$ don't remember the name, Luria (1986) argues that these phenomena are not due to memory failures, but to language functioning and its complexity. According to the author, the necessary selectivity to operate with linguistic units gets lost, what is in agreement with Jakobson's explanation of the two main types of aphasia, approached earlier in this chapter.

\section{TOWARDS A BETTER UNDERSTANDING OF LINGUISTIC- COGNITIVE PROCESSES UNDERLYING WFD}

I hope that the data brought to the second part of this article not only illustrated the theoretical-methodological and ethical issues presented in the beginning of my reflection, but have also allowed the readers a glimpse of the semantic-lexical processes that occur in "slow motion" in aphasia (Coudry [1986], 1988), while the subject works on language resources in order to produce meanings.

WFD, as discussed previously, is a broad concept that hides the relationships among a wide range of terms in aphasia semiology. The quantitative/static methodology is mostly concerned with classifications and this is mainly the reason to approach the phenomena as "symptoms". One of our concerns, when recurring to the aphasic semiology, is to dialogue with other researchers. As Porter (1997) has signed, terminology must be understood as "linguistic coins" that make possible the exchanges within a scientific community ${ }^{39}$. The richness of the phenomena, however, is only perceived when we highlight the underlying processes and establish the relationship between what and how a phenomenon is produced, which is only possible in a qualitative approach. .

We have seen that a word is not a mere designation of an object, an action or a quality. There are not fixed or permanent meanings underlying a word; there is always a multidimensional system of enlaces (Luria, 1986). This conception helps

${ }^{39}$ Porter (1997) states that having a "name" for each disease has to do with the need of the doctors to develop a technical semiology that would serve either to communicate, but also to "(des) communicate with the patient" (Novaes-Pinto and Santana, 2009a; Novaes-Pinto and Santana, 2009b). 
us understand why, in aphasia states, emerge with equal probability words that are similar (phonological, conceptual or situational) to the "exact word", referred to as "target word" in literature.

As linguists, we may add to Luria's reflection the fact that each word in the language has its own history, on the one hand, and that all subjects have their own history with each word of the language, on the other (Ponzio, 2013 apud Oliveira 2017); Oliveira, [2015], 2017). These assumptions are implicit in the concepts of "activity" and "subjectivity" discussed at the beginning of the article.

I would like to close this reflection with the words of Bakhtin, an author I have always recurred to help me express the beauty of language in its relation to the subjects' concrete lives:

For a word is not a material thing but rather the eternally mobile, eternally fickle medium of dialogic interactions. It never gravitates toward a single consciousness or a single voice. The life of the word is contained in its transfer from one mouth to another from one context to another context, from one social collective to another, from one generation to another generation. In this process, the word does not forget its own path and cannot completely free itself from the power of these concrete contexts into which it has entered. [...] When a member of a speaking collective comes upon a word, it is as a neutral word of language, not as a word free from the aspirations and evaluations of others, uninhabited by others voices. No, he receives the word from another's voice and filled with that other voice (Bakhtin, 1984, p. 2002).

Finally, I hope the reflections brought to this article could give the readers the dimension of the theoretical-methodological reach of the approach developed in the field, since the very first work of Coudry, more than thirty years ago.

\section{ACKNOWLEDGEMENTS}

I would like to thank very much my doctoral students Larissa Mazuchelli and Arnaldo Lima for reviewing my text in English, for their interest, suggestions and kind comments. It has been a great pleasure working with them along the years. Thanks also to Thalita Souza-Cruz, for reviewing the French version of the abstract.

Fernanda Freire, thank you for the fruitful discussions not only along the production of this article, but throughout the process of organizing the volume of Cadernos de Estudos Linguísticos [CEL - Vol. 60 (2)].

I also thank FAPESP (Fundação de Amparo à Pesquisa do Estado de S. Paulo), CAPES (Coordenação de Aperfeiçoamento de Pessoal de Nível Superior) and CNPq (Conselho Nacional de Pesquisa) for the support given to our research.

\section{REFERENCES}

ABAURRE, M. B. (1996). Os estudos linguísticos e a aquisição da escrita [The linguistic studies and the acquisition of writing]. In: CASTRO, M. F. (Org.) O Método e o Dado no Estudo da Linguagem, p. 111- 164. Campinas: Editora da Unicamp. 
ALGAVE, D. (2012). Alterações de linguagem nas epilepsias: um estudo neurolinguístico [Language alterations in epilepsies: a neurolinguistic study]. Dissertação de Mestrado (Inédita). Instituto de Estudos da Linguagem, UNICAMP.

ANDRÉ, M. (1984). Estudo de caso: seu potencial na educação [Case study: its potential in Narciso's Diary: assessment and language longitudinal follow-up of aphasic subjects from a discursive perspective education]. Cadernos de Pesquisa, n. 49, p. 51-54.

BAKHTIN, M. ([1929] 1997). Os gêneros do discurso. In Estética da Criação Verbal. [Speech Genres \& Other Late Essays]. São Paulo. Martins Fontes.

BAKHTIN, M. (1984). Problems of Dostoievsky's poetics. Minneapolis: University of Minnesota Press.

BEILKE, H. M. (2009). Linguagem e Memória na Doença de Alzheimer: Contribuições da Neurolinguística para a Avaliação de Linguagem [Language and Memory in Alzheimer Disease: Contributions from Neurolinguistics to Language Assessment]. Dissertação de Mestrado (Inédita). Instituto de Estudos da Linguagem, UNICAMP.

BOCCATO, D. (2018). Paralexia: compreendendo o fenômeno a partir de um estudo de caso no contexto das aphasias [Paralexia: understanding the phenomenon from a case study]. Dissertação de Mestrado (Inédita). Instituto de Estudos da Linguagem, UNICAMP.

BURKE, D. M.; SHAFTO, M. A. (2004). Aging and language production. Curr Dirr Psychol Sci, v. 13, n. 1, p 21-24.

CAMILlO, M. (2017). Avaliação neurolinguística na Doença de Parkinson: um estudo com sujeitos submetidos à estimulação cerebral profunda [Neurolinguistic assessment in Parkinson Disease: a study with subjects submitted to DBS]. Tese de Doutorado (Inédita). Instituto de Estudos da Linguagem, UNICAMP.

CANGUILHEM, G. (1985). O normal e o patológico [On the normal and the pathological]. Ed. Forense Universitária, Rio de Janeiro, RJ.

COUDRY, M. I. H. (1986). Diário de Narciso: avaliação e acompanhamento longitudinal de linguagem de sujeitos afásicos de uma perspectiva discursiva. Tese de Doutorado. [Narciso's Diary: [Narciso's Diary: assessment and language longitudinal follow-up of aphasic subjects from a discursive perspective] Instituto de Estudos da Linguagem, IEL/UNICAMP. Campinas, SP.

COUDRY, M. I. H. ([1988] 2001). Diário de Narciso - discurso e afasia. [Narciso's Diary: discourse and aphasia]. Martins Fontes. IEL/UNICAMP. Campinas.

COUDRY, M. I. H. (1996). O que é o dado em neurolinguística? [What is the data in Neurolinguistics] In: Castro, M. F. (1996). O método e o dado no estudo da linguagem, pp. 179-194, Editora da Unicamp, Campinas, São Paulo, Brasil.

COUDRY, M. I. H. (2002). Linguagem e afasia: uma abordagem discursiva da Neurolinguística. [Language and aphasia: a discursive approach to Neurolinguistics] In Cadernos de Estudos Linguísticos, Vol. 42, p. 99-129.

COUDRY, M. I. H. (2008). Neurolinguística Discursiva; Afasia como tradução [Discursive Neurolinguistics: aphasia as translation]. Estudos da Língua(gem), Vol. 6 (2), p. 7-36. 
COUDRY, M.I; NOVAES-PINTO, R. C. (1994). Análise Neurolinguística de Dados de Versões Protocolares [Neurolinguistic Analysis of Data of P. In: Anais do GEL, Vol. XXIV, p. 192-197.

DAMICO, J. SIMMONS-MACKIE, N., OELSCHLAEGER, M., ELMAN, R.; ARMSTRONG, E. (1999a). Qualitative methods in aphasia research: basic issues. Aphasiology, Vol. 13 ( N. 9- 11), p. 651-665.

DAMICO, J.; OELSCHLAEGER, M.; SIMMONS-MACKIE, N. (1999b). Qualitative methods in aphasia research: conversation analysis. Aphasiology, Vol. 13, n. 9-11, p. 667-679.

FRANCHI, C. (1977). Linguagem - atividade Constitutiva. [Language - Constitutive Activity] Almanaque, 5. São Paulo, SP

FREITAS, M. T. (2010). No fluxo dos enunciados, um convite à pesquisa [In the chain of utterances, an invitation to research]. In: FREITAS, M.T.; RAMOS, B. Fazer pesquisa na abordagem histórico-cultural: metodologias em construção. Juiz de Fora: Editora UFJF.

GIL, A. C. (1995). Métodos e Técnicas da Pesquisa Social [Methods and Techniques of Social Research]. São Paulo: Atlas Editora.

GOODGLASS, H. (1976). Agrammatism. In: Whitaker \& Whitaker (Eds.): Studies in Neurolinguistics (Vol. 1). New York: Academic Press.

GRODZINSKY, Y. (1984). The syntactic characterization of Agrammatism. In Cognition, 16, p. 99120.

JAKOBSON, R. (1954). Dois aspectos da linguagem e dois tipos de afasias. In: Linguística e Comunicação. [Linguistics and Communication]. São Paulo: Cultrix.

JACKSON, J. H. (1874). On the Nature of the Duality of the Brain. The Medical Press and Circular, $1,41-44$.

KEARNS, K. (1999). Qualitative research methods in aphasia: a welcome addition. Aphasiology, Vol. 13, n. 9-11, p. 649-650.

LEONTIEV, A. N. (1982). Activity and Consciouness. Philosophy in the USSR, Problems of Dialectial Materialism. Progress Publishers, Moscow, p. 180-202.

LIMA, A. R. (2017). As palavras funcionais na chamada "fala telegráfica" em enunciados de sujeitos afásicos. [The functional words in the so-called "telegraphic speech in aphasic subjects' utterances]. Dissertação de Mestrado. Inédita. IEL/UNICAMP.

LIMA, A. R.; NOVAES-PINTO, R. C. (2017). "A chamada 'fala telegráfica' e sua relação com as dificuldades de encontrar palavras: uma reflexão a partir de enunciados de sujeitos afásicos não-fluentes. [The so-called 'telegraphic speech' and its relation with word finding difficulties]. Revista Estudos Linguísticos. Vol. 46 (2). p. 715-729.

LURIA, A. (1973). The working brain. Penguin Books, London.

LURIA, A. (1976). Cognitive Development: its cultural and social foundations. Harvard University Press, Cambridge Massachusetts. 
LURIA, A. (1977). Neuropsychological studies in aphasia. Sweets \& Zeitlinger Ed., Amsterdam.

LURIA, A. (1986). Pensamento e Linguagem: as últimas conferências de Luria. [Thought and Language: the last conferences of Luria]. Artes Médicas Editora. Porto Alegre, RS.

LYON, J. (1999). A commentary on qualitative research in afasia. Aphasiology. Vol. 13, n. 9-11, p. 689-690.

MAZUCHELLI, L. (2013). O efeito de práticas sociais com leitura e escrita no caso de uma afasia progressiva. [The effect of social practice with reading and writing in a progressive aphasia case]. Dissertação de Mestrado. Unicamp, Campinas, SP.

MAZUCHELLI, L. (2017). A Dificuldade de Encontrar Palavras: inferências a partir da análise qualitativa de entrevistas com sujeitos idosos. [WFD: inferences from the qualitative analysis of interview with aged subjects]. Estudos Linguisticos, Vol. 46 (2), p. 730-744.

MAZUCHELLI, L. (2018). A linguagem nos processos de envelhecimento normal e patológico na perspectiva da Neurolinguística [Language in the processes of normal and pathological aging in the perspective of Neurolinguistics]. Versão para qualificação de tese. Fapesp/Relatório Parcial.

MICELI, G. (2001). Disorders of Single Word Processing. Journal of Neurology, n. 248, p. 658-664.

NOVAES-PINTO, R. C. (1992). Agramatismo: contribuições para o estudo do processamento normal da linguagem. [Agrammatism: contributions to the study of language normal processing] Dissertação de Mestrado. (Inédita), IEL/UNICAMP.

NOVAES-PINTO, R. C. (1997). Agramatismo e processamento normal da linguagem [Agrammatism and language normal processing]. Cadernos de Estudos Linguísticos, Vol. 32, p. 73-85.

NOVAES-PINTO, R. C. (1999). Contribuição dos estudos discursivos para uma análise crítica das categorias clínicas. [The contribution of discursive studies for a critical analysis of clinical categories]. Tese de Doutorado. Inédita. Instituto de Estudos da Linguagem. UNICAMP, Campinas, S.P.

NOVAES-PINTO, R. C. (2008). Preconceito Linguístico e Exclusão Social. [Linguistic Prejudice and Social Exclusion]. Avesso do Avesso: Revista de educação e cultura. Faculdade da Fundação Educacional de Araçatuba/SP (ISSN: 1678-7862), Vol. 5, n. 5, p. 8 - 36, Araçatuba, SP, 2009.

NOVAES-PINTO, R. C. (2009). Dificuldades para encontrar palavras e produção de parafasias nas afasias e nas demências: inferências para o estudo do funcionamento semântico-lexical e sua organização em redes semânticas [Word Finding Difficulties and the production of paraphasias in afasia and in dementia: inferences to the study of semantic-lexical functioning and its organization in semantic categories]. (Inédito). Projeto de Pesquisa, CNPq.

NOVAES-PINTO, R. C. (2012a). Cérebro, linguagem e funcionamento cognitivo na perspectiva sóciohistórico-cultural: inferências a partir do estudo das afasias. [Brain, language and cognitive functionin in the sócio-historical-cultural perspective] Letras de Hoje. Vol. 47(1), p. 55-64.

NOVAES-PINTO, R. C. (2012b) A social cultural approach to aphasia: contributions from the work developed in a center for aphasic subjects. In: Uner, Tan. Latest Findings in Intellectual and Developmental Disabilities Research. In Tech Open Access. Rijka, Croácia, p. 219-244. 
NOVAES-PINTO, R. C. (2013) Dificuldades para encontrar palavras e produção de parafasias nas afasias e nas demências: inferências para o estudo do funcionamento semântico-lexical e sua organização em redes semânticas [Word Finding Difficulties and the production of paraphasias in afasia and in dementia: inferences to the study of semantic-lexical functioning and its organization in semantic categories]. Relatório de Pesquisa do CNPq, Processo 308214/2009-9.

NOVAES-PINTO, R. C.; OLIVEIRA, M. (2014). Uncovering hidden meanings in legal discourse on the elderly: a semioethical perspective. In Semiotica (online).

NOVAES-PINTO, R. C.; SANTANA, A. P. (2009a). Semiologia das afasias: Implicações para a clínica fonoaudiológica [Semiology of aphasia: implications for the Speech Therapy Clinic]. In Perspectivas na Clínica das Afasias: o sujeito e o discurso. São Paulo, SP, Brasil: Editora Livraria Santos.

NOVAES-PINTO, R. C.; SANTANA, A. P. (2009b). Semiologia das afasias: uma discussão crítica [Semiology of Aphasias: A Critical Discussion]. In Psicologia: Reflexão e Crítica, 22(3): 413421 ..

NOVAES-PINTO, R. C.; SOUZA-CRUZ, T. C. (2012). Funcionamento semântico-lexical: discussão crítica com base em dados de situações dialógicas com sujeitos afásicos. [Semantic-lexical functioning: a critical discussion based in data of dialogical situations with aphasic subjects]. Estudos Linguísticos. Vol. 41, p. 708-722.

OLIVEIRA, M. V. B. (2015). Palavras na ponta da língua: um estudo neurolinguístico. [Tip-of-thetongue words: a Neurolinguistic study]. Tese de Doutorado. Instituto de Estudos da Linguagem, Unicamp.

OLIVEIRA, M. V. B. (2017). Palavras na ponta da lingua: um estudo neurolinguístico. [Tip-of-thetongue words: a Neurolinguistic study]. São Carlos: Pedro \& João Editores.

OLIVEIRA, M. V. B.; NOVAES-PINTO, R.C. (2014). On the relation between memory and language from a historical-cultural perspective in neurolinguistics. Southern Semiotic Review, v. 4, p. $1-15,2014$.

PONZIO, A. A memória da palavra e a memória do falante. [The word's memory and the speaker's memory] Notas de mesa-redonda, iII Encontro Contribuições de Bakhtin à Linguística e à Educação, IEL/UNICAMP, 2013.

PORTER, R. (1997). Expressando sua enfermidade: A linguagem da doença na Inglaterra Georgiana. [Expressing yourself ill: the language of sickness in Georgian England] In P. Burke e R. Porter (Eds.) Linguagem, individuo e sociedade: História social da linguagem [Language, Self and Socity: A history of language], p. 365-394. São Paulo, SP: Editora da Universidade do Estado de São Paulo.

PRETI, D. A linguagem dos idosos. [The anguage of the Elderly] São Paulo: Ed. Contexto, 1991.

SAUSSURE, F. (1916) Cours de Linguistique Générale. Payot. Paris.

SHAFTO, M.A., BURKE, D.M.; STAMATAKIS, E.A.; TAM, P.P., TYLER, L.K. (2007). On the tipof-the-tongue: neural correlates of increased word-finding failures in normal aging. J. Cogn. Neurosci. Dec 19(12): 2060-70. 
SIMMONS-MACKIE, N.; DAMICO, J. (1999). Qualitative methods in aphasia research: ethnography. Aphasiology. Vol. 13 (n. 9-11), p 681-687.

SOUZA-CRUZ, T. C. (2014). Em briga de marido e mulher, ninguém mete o garfo: estudo discursivo da produção de parafasias literais e semânticas [In a quarrel between a husband and a wife, nobody puts the fork: a discursive study on the production of literal and semantic paraphasias]. Dissertação de Mestrado. Inédita. Instituto de Estudos da Linguagem, UNICAMP.

SOUZA-CRUZ , T. C. (2017). Entrando pelo you-tubo: estudo neurolinguístico das categorizações semântico-lexicais [Entrando pelo you-tube: a neurolinguistic study of semantic-lexical categorization). Tese de Doutorado (Inédita). Instituto de Estudos da Linguagem, UNICAMP.

SOUZA-CRUZ , T. C.; BOCCATO, D. (2017). Produção de parafasias e paralexias e sua relação com as 'dificuldades de encontrar palavras'. [Production of paraphasia and paralexia and their relation with WFD”. Estudos Linguísticos, Vol. 46 (2), p. 760-773.

TISSOT, R.; MOUNIN, F.; LHERMITTE, F. (1973). Agrammatisme. Etude neuropsycholinguistique. Bruxelles: Dessar.

STAKE. R. E. (2000). Case studies. In: DENZIN, N. K.; LINCOLN, Y. S. (ed.) Handbook of qualitative research. London: Sage, p. 435-45.

VYGOTSKY, L. ([1930] 1984). A formação social da mente (Mind in society: The Development of Higher Psychological Processes, 1930), São Paulo: Martins Fontes.

VYGOTSKY, L. ([1934], 1987). Thought and language. São Paulo: Martins Fontes. 